\title{
Analysis of the Effect of Intake Valve Fin Adding of Dual Fuel Engine on the Performance-Based Experiment
}

\author{
Semin $^{\mathrm{a}, 1}$, Rosli Abu Bakar ${ }^{\mathrm{b}}$, Linggar Palang Aras RFC ${ }^{\mathrm{a}}$ \\ ${ }^{a}$ Department of Marine Engineering, Institut Teknologi Sepuluh Nopember, Surabaya, 60111, Indonesia \\ E-mail: ${ }^{1}$ seminits@gmail.com \\ ${ }^{b}$ Faculty of Mechanical Engineering, Universiti Malaysia Pahang, Pekan, 26600, Malaysia \\ E-mail: rosli@ump.edu.my
}

\begin{abstract}
The modification of diesel engine into the dual-fuel engine or specifically gas - oil fuel engine has been done to solve the problem of the depletion fossil fuel oil reserves in the world. Fossil fuel oil reserves are projected to be exhausted in the next 50 years or less by prediction. The working system of the gas - oil fuel engine was injecting (gas fuel) to combustion chamber along with the air during the suction step in the intake manifold and burned with the diesel as the lighter. The gas fuel was used here is CNG (Compressed Natural Gas). But the performance of the engine when using the addition of gas fuel has decreased. The modification, like the addition of fixed fin in the air intake valve, is done to increase the swirl ratio. So, that turbulent flow of air comes in along with the gas fuel to be better. As a result, the combustion process in the combustion chamber got better. By applying a fixed fin addition into the air intake valve gas-oil fuel engine, it can increase engine performance better. The power generated by the engine with fin adding increases at maximum load. While torque of engine with fin adding increased in maximum load condition. For specific energy consumption (SEC) has been decreased impact of the fin, adding on the air intake valve.
\end{abstract}

Keywords — CNG; engine performance; gas-oil fuel engine; intake valve fin; turbulent flow.

\section{INTRODUCTION}

The use of gas fuel as an energy source is one of the many efforts that can to be made to replace fuel oil as an alternative fuel [1]-[3]. There are many types of gas fuel, such as natural gas and petroleum gas. In the storage and distribution of natural gas consists of two forms, namely, compressed natural gas (CNG) and liquefied natural gas (LNG) [4]-[6]. Compressed natural gas (CNG) is an alternative fuel besides gasoline or diesel [7]. This fuel is cleaner than fuel oil. CNG is very kind with environmental when compared to fuel oil due to its friendly exhaust emissions. $\mathrm{CNG}$ is made by compressing methane $(\mathrm{CH} 4)$ extracted from natural gas. The gas is mixed with fresh air in the air intake manifold (or injected into the cylinder) and inserted into the combustion chamber ignited by a small amount of diesel fuel when the piston approaches the end of the compression step (TDC) [8]-[10].

From 2010 to 2015, many studies show that there is a significant reduction in emissions in the presence of CNGdiesel fuel and other alternative fuels when compared to conventional diesel engines. The advantage using CNG on diesel engine emissions produces particulate matters (PM), hydrocarbons $(\mathrm{HC})$, carbon monoxide $(\mathrm{CO})$, carbon dioxide
(CO2) and nitrogen oxide (NOx), has been decreased significantly. Still, thermal efficiency has been decreased too [9]-[15]. CNG has many benefits and has almost no negative impact that provides the perfect to become the next alternative fuel changing fuel oil for our world to rely on reasonably. But it is not maximized yet, and its utilization is not optimized [16]. In previous research, the explanation of the difference in the fuel ratio of diesel engines with gas-oil fuel engines has considerable differences. The amount of fuel in the gas-oil fuel diesel engine causes an increase in the gas fuel mass flow rate $(\mathrm{CNG})$, although, with the addition of fuel gas, the mass flow rate of diesel oil is reduced [17]. The factors that are discussed in this paper are the factors of mixing air and fuel. This effect of air mixing caused significant diffusion coefficients for mass transfer and heat momentum, but there is a loss in energy because of turbulence flow has also been better than laminar flow [18]. This effect on the vortices occurs work against viscous stress so that the energy-containing in the cylinder must be dissipated into heat. Evident in the research using the loading resulted in reduced air and fuel ratio [19]-[25]. This is due to a decrease in the initial injection and the injection duration to the engine combustion chamber. The condition of the dual-fuel engine with the fin adding on intake valve- 
based simulation has been increased the turbulent flow in the combustion chamber of the engine [25-28]. The objective of this paper is to investigate the effect of fin adding on the intake valve of dual fuel (gas-oil) engine on the performance based on the experiment. The engine performance calculations based on the experiment is below:

\section{A. Engine Power Output}

The power output is the parameter for determining the engine performance. The engine power output is the extensive work engine efforts over time [8].

$$
P=\frac{V \times I \times \operatorname{Cos} \emptyset}{\text { eff.gen } x \text { eff.slip }}
$$

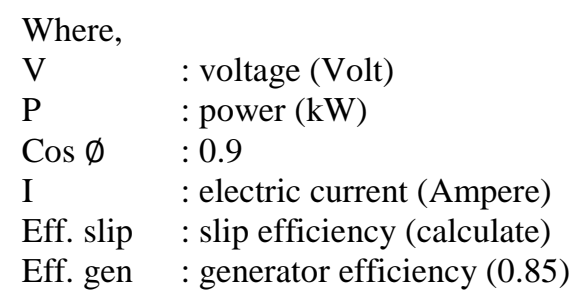

\section{B. Engine Torque}

The amount of engine torque is commonly used to calculate the energy generated of objects spinning on its axis of the engine [8].

$$
T=\frac{P \times 60000}{2 \pi \times r p m}
$$

Where,

$$
\begin{array}{ll}
\mathrm{P} & \text { : power }(\mathrm{kW}) \\
\mathrm{T} & \text { : torque }(\mathrm{Nm}) \\
\mathrm{Rpm} & \text { : rotation of diesel engine }(\mathrm{rpm})
\end{array}
$$

\section{Engine Specific Fuel Oil Consumption (SFOC)}

The engine specific fuel oil consumption (SFOC) is the parameter offered engine work that direct contact with economic value an engine, it can be counted the amount of fuel that required to produce of power [8]:

$$
F C R=\frac{V x \rho}{t}
$$

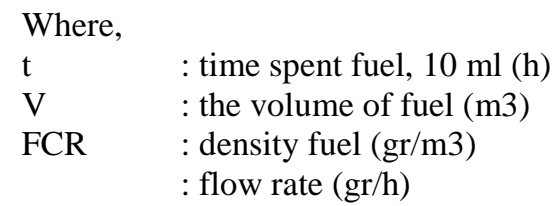

Where:

$$
S F O C=\frac{F C R}{P}
$$

$$
\begin{array}{ll}
\mathrm{P} & : \text { Power }(\mathrm{kW}) \\
\mathrm{FCR} & : \text { flow rate }(\mathrm{gr} / \mathrm{h}) \\
\text { SFOC } & : \text { specific fuel consumption }(\mathrm{gr} / \mathrm{kWh})
\end{array}
$$

\section{Engine Specific Energy Consumption (SEC)}

The specific energy consumption (SEC) is the parameter offered engine work that direct contact with the economic value an engine, with know this can be counted the amount of energy that required to produce power [8]:

$$
S E C=\frac{(\mathrm{m} \times \mathrm{LHV}) \times S F O C}{1000}
$$

Where,

SFOC : specific fuel consumption $(\mathrm{kg} / \mathrm{kWh})$

$\mathrm{m} \quad$ : mass of fuel $(\mathrm{kg})$

SEC : specific energy consumption $(\mathrm{kJ} / \mathrm{kWh})$

LHV : low heating value $(\mathrm{J} / \mathrm{kg})$

\section{MATERIAL AND METHOD}

The specification of the engine was used in this research is shown in table 1 .

TABLE I

ENGINE SPECIFICATIONS

\begin{tabular}{|l|l|}
\hline Specification & Explication \\
\hline Engine (four stroke cycle) & Yanmar TF 85 MH \\
\hline Number of cylinders & 1 \\
\hline Combustion system & Direct Injection \\
\hline Bore & $85 \mathrm{~mm}$ \\
\hline Stroke & $87 \mathrm{~mm}$ \\
\hline Displacement & $493 \mathrm{cc}$ \\
\hline Compression Ratio & 18 \\
\hline Max. Engine speed at full load & $2200 \mathrm{RPM}$ \\
\hline Continuous Power Output & $7.5 \mathrm{~kW}$ \\
\hline Specific Fuel Consumption & $229.31 \mathrm{gr} / \mathrm{kWh}$ \\
\hline
\end{tabular}

\section{A. Modification of Air Intake Valve}

Measurement of the air intake valve is done to make modifications with the adding of the fixed fin on the valve. Measurements were made before modelling the design to get a modified air intake valve design. By removing the intake valve from cylinder head of the Yanmar TF $85 \mathrm{MH}$ engine, a real air intake valve size is obtained. Noteworthy in this step that the fixed-size fin size should not be rubbed against the valve sitting [28-30].

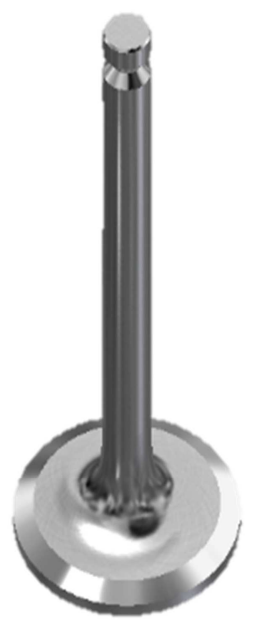

(a)

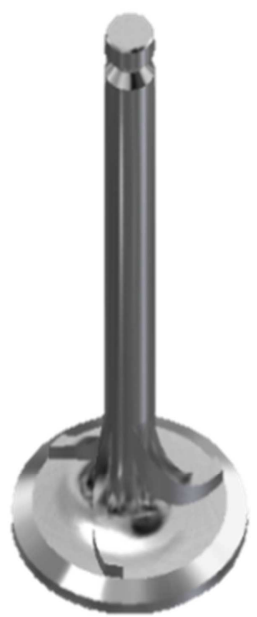

(b)

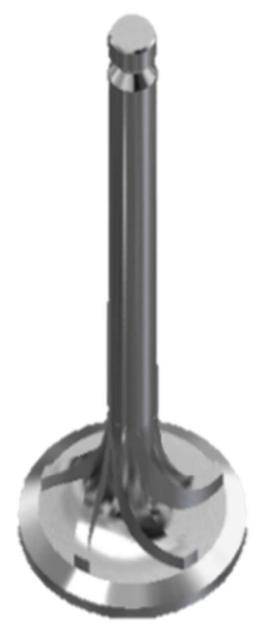

(c)
Fig. 1 Design of Fin Adding on Intake Valve. a. original, b. 3 fins, c. 5 fins

Process of manufacturing air intake valve by using the argon welding engine because the size of the air intake valve is tiny. After going through the argon welding stage, smoothing is done using a grind and a dresser engine. The effect of this modification must be strong enough to resist 
high temperature [30]. The temperature in the combustion chamber is up to $500^{\circ} \mathrm{C}$ so that the material used in the modification of air intake valve must have high resistance with high temperature. At least, material to manufacture the fin addition have the same hardness with the material of air intake valve itself. Beware of intake valve sitting [29].

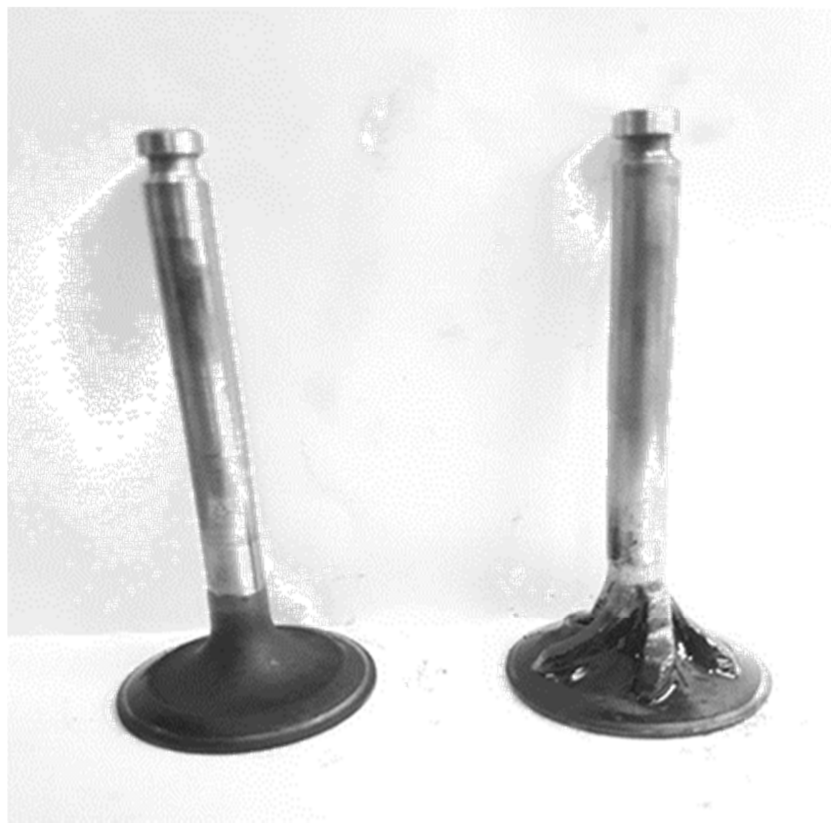

Fig. 2 Comparison of Air Intake Valve
Engine set-up is done to prepare all forms of preparation for Yanmar TF $85 \mathrm{MH}$ engine to be ready for the experiment. The engine used is an engine that has been modified to gas oil fuel engine CNG - fuel. In this phase, it should be considered because it can impact the results of the experimental data. Figure 3 shows the scheme of the experiment. After engine preparation has been done, we can determine variable such as below:

- Fuel Variation:

1. Pertamina DEX $100 \%$

2. Pertamina DEX +1 litre per minute of $\mathrm{CNG}$

3. Pertamina DEX +2 litre per minute of $\mathrm{CNG}$

4. Pertamina DEX + 3 litre per minute of $\mathrm{CNG}$

- Variable of load:

1. 4000 watts

2. 3000 watts

3. 2000 watt

4. 1000 watt

- Variable of engine rpm:

1. $2200 \mathrm{rpm}$

1. $2100 \mathrm{rpm}$

2. $2000 \mathrm{rpm}$

3. $1900 \mathrm{rpm}$

4. $1800 \mathrm{rpm}$

- Results Variable on Performance Test:

1. Torque

2. Power

3. Specific Energy Consumption (SEC)

4. Specific Fuel Oil Consumption (SFOC)

\section{B. Engine Set-up}

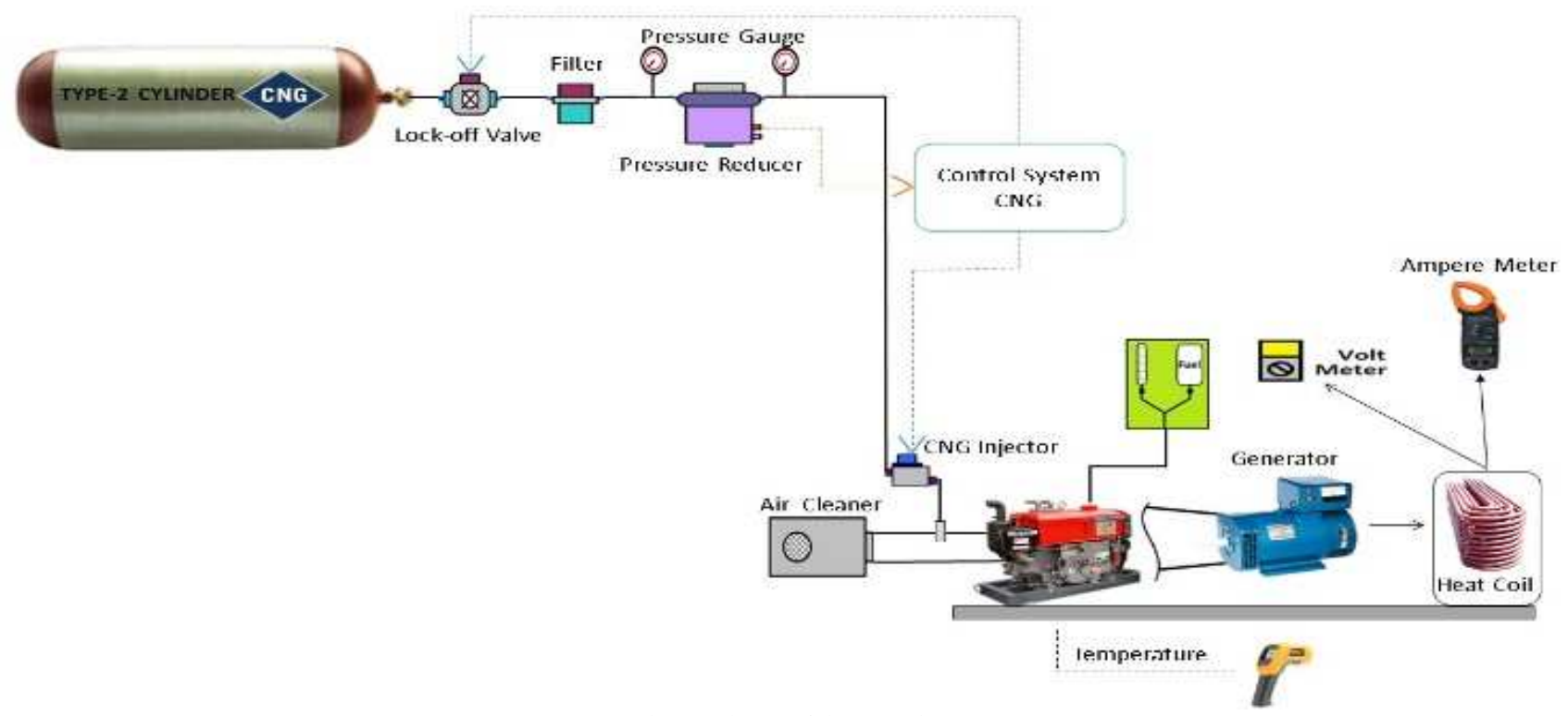

Fig. 3 Scheme of the Experiment

\section{RESULTS AND DISCUSSION}

This section is presented based on three main issues. The first issue is about the effect of fin addition on air intake valve diesel engine to engine performance. The second issue is the effect of fin addition on air intake valve gas - oil fuel engine to engine performance. The last issue to be presented in this section is the comparison between the performance of the diesel engine and gas-oil fuel engine with fin addition on the air intake valve.

\section{A. Effect of Fin Adding on Diesel Engine Performance}

To analyze section-to-section, first of all, analysis has been done about power, torque, and specific energy consumption of diesel engine and gas-oil fuel engine. Engine's performance here uses full load to compare where better when using air intake valve with fin addition or not. Final data analysis has shown the best results in all comparison. Figure 4 shows power when using fin addition on the air intake valve. 


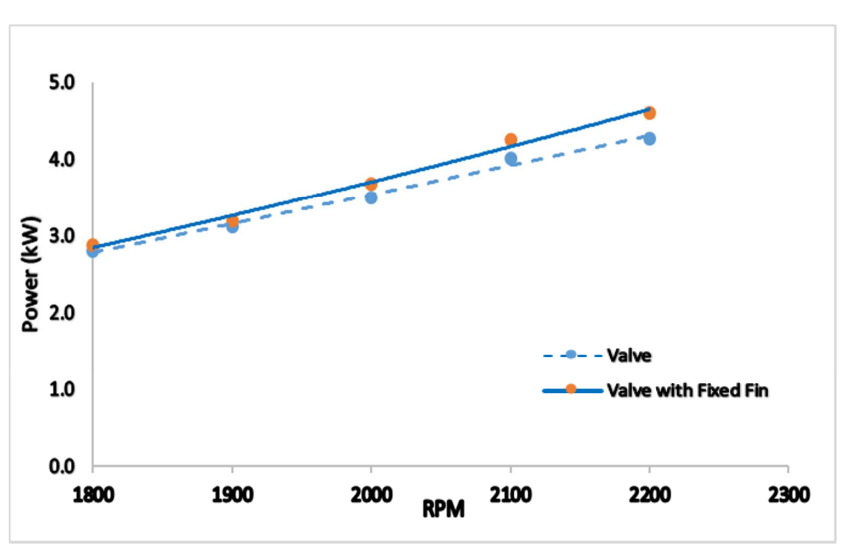

Fig. 4 Power vs rpm on diesel engine

Figure 4 shows that higher the rpm of the engine, higher the power generated during full load. At $1800 \mathrm{rpm}$, maximum power when using air intake valve and air intake valve with the addition of fixed fin respectively that is 2.8 $\mathrm{kW}$ and $2.9 \mathrm{~kW}$. While at the $1900 \mathrm{rpm}$, the maximum power of $3.1 \mathrm{~kW}$ and $3.2 \mathrm{~kW}$ respectively between the air intake valve and air intake valve with the addition of fixed fin. At $2000 \mathrm{rpm}$, obtained $3.5 \mathrm{~kW}$ and $3.7 \mathrm{~kW}$ of power with modified air intake valve without the addition of fixed fin and by the addition of fixed fin. Then the power generated $4 \mathrm{~kW}$ without the addition of fixed fin and 4.25 $\mathrm{kW}$ with the addition of fixed fin at rpm 2100. At the time of $2200 \mathrm{rpm}$, the maximum power when using air intake valve and air intake valve with the addition of fixed fin is $4.2 \mathrm{~kW}$ and $4.6 \mathrm{~kW}$.

This shows that the effect of fixed fin addition on air intake valve can improve engine power performance at 2200 rpm up to $10 \%$ in full load state. This is because when using the addition of fixed fin on the air intake valve causes the airflow rate to be more turbulent, which increases the swirl ratio of the incoming mixing airflow. So, the combustion process gets better. The effects on knocking and ignition delay because knocking on engine never get serious attention. It can impact on engine noise and vibration, which can make engine component become crash or deflect.

In Figure 5 shows that the higher the rpm of the engine, the higher torque generated during full load. At $1800 \mathrm{rpm}$, maximum torque when using air intake valve and air intake valve with the addition of fixed fin respectively that is 14.9 $\mathrm{Nm}$ and $15.2 \mathrm{Nm}$. Where, when engine at $1900 \mathrm{rpm}$, maximum torque of $15.6 \mathrm{Nm}$ and $16 \mathrm{Nm}$ respectively between the air intake valve and air intake valve with the addition of fixed fin. At $2000 \mathrm{rpm}, 16.7 \mathrm{Nm}$ and $17.6 \mathrm{Nm}$ of torque were obtained with a modified air intake valve without the addition of fixed fin and with the addition of fixed fin. Then the torque generated $18.2 \mathrm{Nm}$ without the addition of fixed fin and $19.4 \mathrm{Nm}$ with the addition of fixed fin at rpm 2100. At the time of $2200 \mathrm{rpm}$, maximum torque when using air intake valve and air intake valve with the addition of fixed fin successively is $18,5 \mathrm{Nm}$ and $19.9 \mathrm{Nm}$. This event shows that the effect of fixed fin addition on the air intake valve can improve engine torque performance at each constant rpm up to $9 \%$.

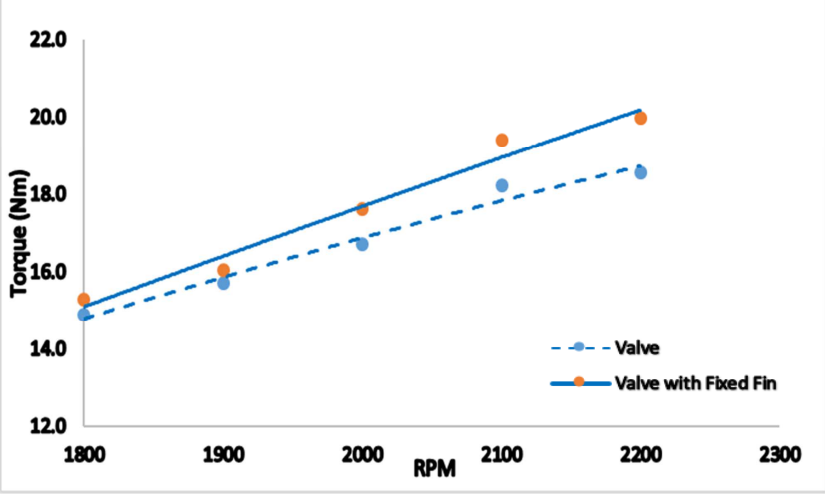

Fig. 5 Torque vs rpm on diesel engine

\section{B. Effect of Fin Adding on Dual Fuel Engine Performance}

This analysis was about the effect of fin addition on the air intake valve on a diesel engine. Then, Figure 6 shows to explain the effect of fin addition on air intake valve gas-oil fuel engine.

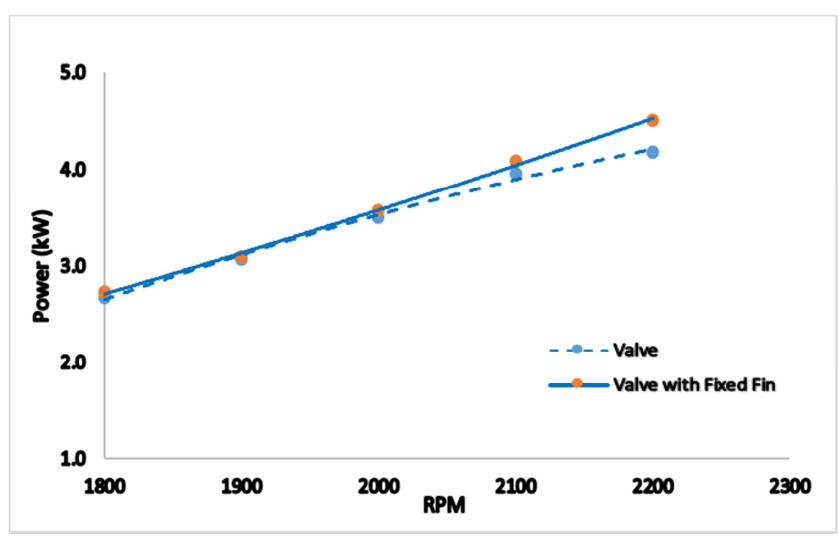

Fig. 6 Power vs rpm on gas-oil fuel engine

Figure 6 shows that the higher rpm of the engine, the higher power generated during full load. At $1800 \mathrm{rpm}$, maximum power when using air intake valve and air intake valve with the addition of fixed fin respectively that is 2.6 $\mathrm{kW}$ and $2.7 \mathrm{~kW}$. Whereas, when on condition $1900 \mathrm{rpm}$, the maximum power of $3.07 \mathrm{~kW}$ and $3.09 \mathrm{~kW}$ respectively between the air intake valve and air intake valve with the addition of fixed fin. At $2000 \mathrm{rpm}$, obtained value $3.5 \mathrm{~kW}$ and $3.6 \mathrm{~kW}$ of power with modified air intake valve without the addition of fixed fin and with the addition of fixed fin. Then the power generated $3.9 \mathrm{~kW}$ without the addition of fixed fin and $4 \mathrm{~kW}$ with the addition of fixed fin at $2100 \mathrm{rpm}$. At rpm 2200, the maximum power when using air intake valve and air intake valve with the addition of fixed fin is 4.1 $\mathrm{kW}$ and $4.5 \mathrm{~kW}$.

This phenomenon shows that the effect of fixed fin addition on air intake valve can improve engine power performance at $2200 \mathrm{rpm}$ up to $10 \%$ in full load condition. Now in Figure 7 shows how the addition of fixed fin on air intake valve affected torque in maximum load [25-26]. 


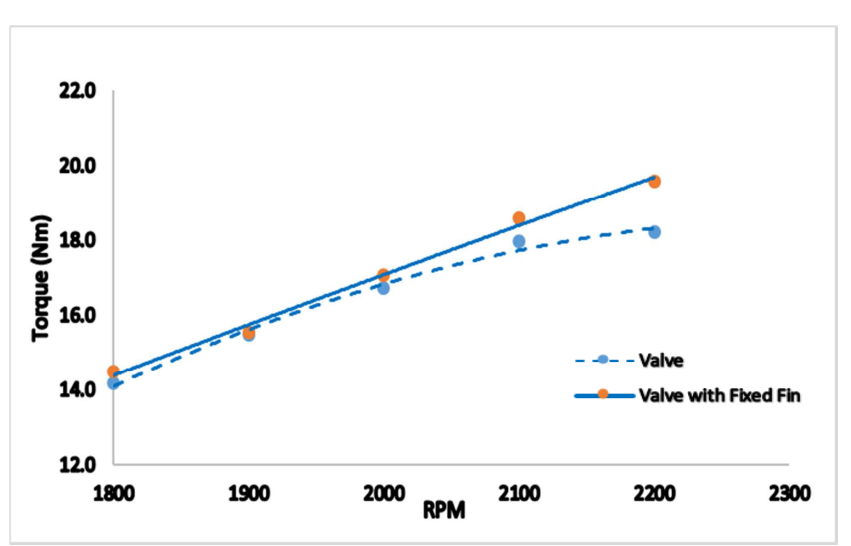

Fig. 7 Torque vs rpm on gas-oil fuel engine

Figure 7 shows that on $1800 \mathrm{rpm}$, maximum torques when using air intake valve and air intake valve with the addition of fixed fin are $14.1 \mathrm{Nm}$ and $14.5 \mathrm{Nm}$, respectively. And then, when $1900 \mathrm{rpm}$, maximum torque of $15.48 \mathrm{Nm}$ and $15.53 \mathrm{Nm}$ respectively between the air intake valve and air intake valve with the addition of fixed fin. At $2000 \mathrm{rpm}, 16.7$ $\mathrm{Nm}$ and $17 \mathrm{Nm}$ of torque were obtained with a modified air intake valve without the addition of fixed fin and with the addition of fixed fin. Then the torque generated $17.9 \mathrm{Nm}$ without the addition of fixed fin and $18.6 \mathrm{Nm}$ with the addition of fixed fin at $2100 \mathrm{rpm}$. At the time of $2200 \mathrm{rpm}$, the maximum torque when using air intake valve and air intake valve with the addition of fixed fin successively is 18 , $2 \mathrm{Nm}$ and $19.6 \mathrm{Nm}$. This shows that the effect of fixed fin addition on the air intake valve can be increased up to $8 \%$ for the torque of the engine on constant rpm.

For the next analysis, the comparison between the air intake valve with the addition of fixed fin and without the addition of fixed fin on each fuel used. So, it can be known how the effect of air intake valve modifications on diesel engine and gas-oil fuel engine. Having discovered the highest power at maximum load then it can be further analyzed how about the highest power and the highest torque relation with the specific energy consumption needed to produce the best power and the best torque. Figure 8 shows the power produced by the engine on each variation of fuel (diesel engine and gas-oil fuel engine) in constant rpm and full load condition [25-30].

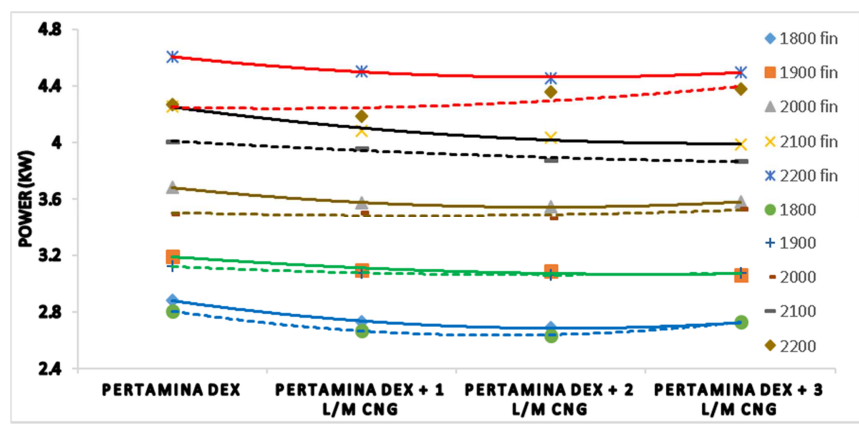

Fig. 8 Power in full load

Based on Figure 8 it can be explained that the difference is quite high when the engine operates at a constant rpm at $2100 \mathrm{rpm}$ and $2200 \mathrm{rpm}$ for maximum load condition. When using the fixed fin addition on the air intake valve, the power increases almost $10 \%$ when operated on diesel engine without CNG blends. The more CNG fuels that enter, the power generated decreases. These phenomena that occur can be seen at a constant rotation of $2200 \mathrm{rpm}$, when getting an additional 1 liter per minute of $\mathrm{CNG}$ the power increases from $4.18 \mathrm{~kW}$ to $4.5 \mathrm{~kW}$. When injected 2 liters per minute of $\mathrm{CNG}$, the power increases from $4.35 \mathrm{~kW}$ to $4.45 \mathrm{~kW}$. However, at the time of addition of 3 liters per minute of $\mathrm{CNG}$, the power increased from $4.37 \mathrm{~kW}$ to $4.49 \mathrm{~kW}$. While the analysis at $2100 \mathrm{rpm}$ constant speed, when diesel engine mode, power increased from $4 \mathrm{~kW}$ to $4.25 \mathrm{~kW}$. At the time of obtaining the injected 1 liter per minute of $\mathrm{CNG}$, the power increased from $3.95 \mathrm{~kW}$ to $4.08 \mathrm{~kW}$. The addition of 2 liters per minute of $\mathrm{CNG}$, power increases from $3.87 \mathrm{~kW}$ to $4 \mathrm{~kW}$. However, at the time of addition of 3 liters per minute of CNG, power only increased $3.87 \mathrm{~kW}$ to $3.98 \mathrm{~kW}$. At a constant rotation of $1800 \mathrm{rpm}, 1900 \mathrm{rpm}$, and $2000 \mathrm{rpm}$ the use of modifications to the addition of fixed fin on air intake valve, the margin of increase is not very significant. So, it can be concluded that the strongest influence of modification with fixed fin addition on air intake valve is at constant rotation $2200 \mathrm{rpm}$ or high speed. And can be further analyzed how energy consumption occurs between the performance of the diesel engine and gas-oil fuel engine.

Before next step to analyze about specific energy consumption, effective torque must be analyzed to get the optimum result. Figure 9 shows about torque produced by engine while on diesel mode and gas-oil fuel engine. There must be a phenomenon when torque of the engine and variation of fuel used technically match.

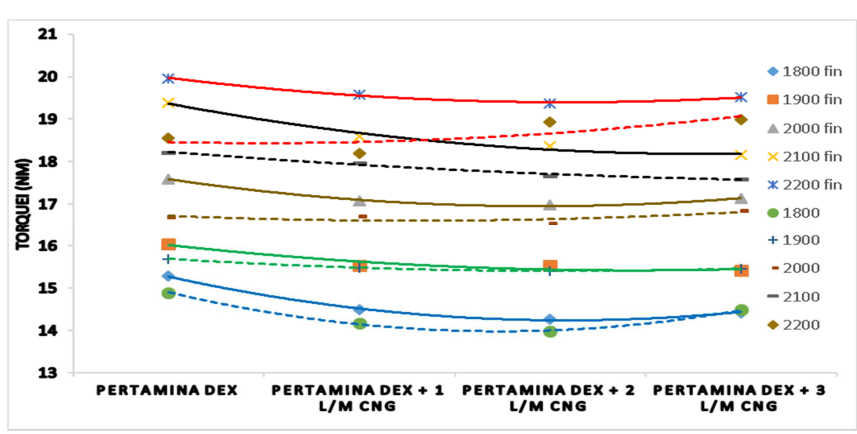

Fig. 9 Torque in full load

Based on Figure 9 it can be explained that the difference is quite high when the engine operates at a constant rotation of $2100 \mathrm{rpm}$ and $2200 \mathrm{rpm}$ maximum load or high speed. When using the fixed fin addition on the air intake valve, the torque increases by almost $10 \%$ when using diesel mode without $\mathrm{CNG}$ blends. The more $\mathrm{CNG}$ fuels that enter combustion chamber, the result make torque decreases. The phenomena that occurs can be seen at a constant rotation of $2200 \mathrm{rpm}$, when without the addition of CNG the torque increases from $18.55 \mathrm{Nm}$ to $19.96 \mathrm{Nm}$. When getting an additional 1 liter per minute of CNG, torque increased from 18.52 $\mathrm{Nm}$ to $19.57 \mathrm{Nm}$. When the addition of 2 liter per minute of $\mathrm{CNG}$, the torque increased from $18.92 \mathrm{Nm}$ to 19.37 Nm. However, at the time of addition 3 liter per minute $\mathrm{CNG}$, the torque increased from $18.98 \mathrm{Nm}$ to 19.5 $\mathrm{Nm}$.

While the analysis at constant speed $2100 \mathrm{rpm}$, when using diesel fuel, torque increased from $18.2 \mathrm{Nm}$ to $19.4 \mathrm{Nm}$. At the time of obtaining the addition of 1 liter per minute of 
$\mathrm{CNG}$, the torque increased from $17.97 \mathrm{Nm}$ to $18.6 \mathrm{Nm}$. When the addition of 2 liter per minute of $\mathrm{CNG}$, the torque increased from $17.66 \mathrm{Nm}$ to $18.35 \mathrm{Nm}$. However, at the time of addition 3 liter per minute of $\mathrm{CNG}$, the torque only increased from $17.59 \mathrm{Nm}$ to $18.16 \mathrm{Nm}$. At a constant rotation of $1800 \mathrm{rpm}, 1900 \mathrm{rpm}$, and $2000 \mathrm{rpm}$ the use of modifications in addition of fixed fin on air intake valve is not very significant and effective. So, it can be concluded that the highest influence of fixed fin usage on air intake valve is at constant rotation $2200 \mathrm{rpm}$ while on diesel mode and gas-oil fuel engine. Further analysis can be focused on how energy consumption occurs between the torque of diesel engine and gas-oil fuel engine.

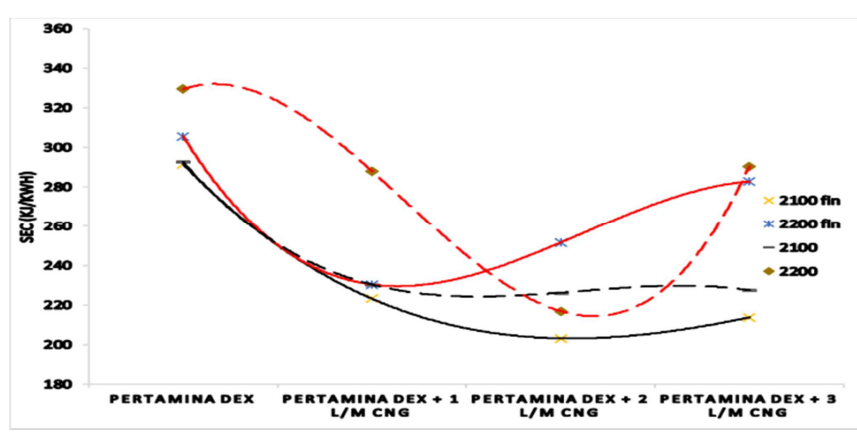

Fig. 10 SEC Comparison

Based on Figure 8 and Figure 9, it can be explained that the effect of using fixed fin modification on air intake valve is significant when the engine operates at a constant rotation of $2200 \mathrm{rpm}$ or high speed. So, it can be analyzed in diesel engine mode and gas-oil fuel engine. Figure 10 shows about how the specific energy consumption needed in that condition.

Based on Figure 8 and 9 known effect of fixed fin addition on air intake valve between diesel engine and gasoil fuel engine optimally at $2100 \mathrm{rpm}$ and $2200 \mathrm{rpm}$ for constant rotation. Energy consumption at constant rotation $2200 \mathrm{rpm}$, while diesel engine the value of air intake valve using fixed fin and without fixed fin are $305,6 \mathrm{~kJ} / \mathrm{kWh}$ and $329,4 \mathrm{~kJ} / \mathrm{kWh}$ respectively. Meanwhile, when the addition of 1 liter per minute of $\mathrm{CNG}$, the value of energy consumption is $230,4 \mathrm{~kJ} / \mathrm{kWh}$ and $288,1 \mathrm{~kJ} / \mathrm{kWh}$ respectively. However, while addition of 2 liter per minute of CNG, fixed fin usage value is higher than without fixed fin with value of 251,7 $\mathrm{kJ} / \mathrm{kWh}$ and $217 \mathrm{~kJ} / \mathrm{kWh}$. And at the addition of 3 liter per minute of $\mathrm{CNG}$, the value of energy consumption using fixed fin and without fixed fin are $282,7 \mathrm{~kJ} / \mathrm{kWh}$ and 290,5 $\mathrm{kJ} / \mathrm{kWh}$.

At a constant rotation of $2100 \mathrm{rpm}$, the consumption of air intake valve usage with fixed fin and without using fixed fin are $291.6 \mathrm{~kJ} / \mathrm{kWh}$ and $292,668 \mathrm{~kJ} / \mathrm{kWh}$ respectively. Meanwhile, when the addition of 1 liter per minute of CNG, the value of energy consumption are $223.2 \mathrm{~kJ} / \mathrm{kWh}$ and $230,4 \mathrm{~kJ} / \mathrm{kWh}$ respectively. However, in the addition of 2 liter per minute of CNG, fixed fin usage value is lower than without fixed fin with a value of $203.2 \mathrm{~kJ} / \mathrm{kWh}$ and 226.25 $\mathrm{kJ} / \mathrm{kWh}$. And at the addition of 3 liter per minute of $\mathrm{CNG}$, the value of energy consumption using fixed fin and without fixed fin is $213,81 \mathrm{~kJ} / \mathrm{kWh}$ and $290,55 \mathrm{~kJ} / \mathrm{kWh}$. So, it can be concluded that the use of fixed fin modification on the air intake valve is not so influential on energy consumption of gas-oil fuel engine due to the composition of air and gas that too much in the combustion chamber. So that there is still remaining fuel that is not burned perfect [25]-[31].

\section{IV.CONCLUSION}

Based on the experimental investigation results and discussion, the paper has conclusions: at the maximum load, the engine power increase is not too significant at a constant rotation of $1800 \mathrm{rpm}, 1900 \mathrm{rpm}$, and $2000 \mathrm{rpm}$. However, when engine operates on high rotation, there is increased of power up to $10 \%$ on diesel engine and $3 \%$ on gas-oil fuel engine. At the maximum load condition, the increasing of engine torque is not very significant at a constant rotation of $1800 \mathrm{rpm}, 1900 \mathrm{rpm}$, and $2000 \mathrm{rpm}$. However, when engine operates on high rotation, there is increased of torque up to $7.6 \%$ in diesel engine and $4 \%$ in gas-oil fuel engine. Specific energy consumption at maximum load when operates on high rotation decreased up to $7.29 \%$ in diesel engine and average decreasing up to $5 \%$ in gas-oil fuel engine.

\section{ACKNOWLEDGMENT}

We would like to thank Institut Teknologi Sepuluh Nopember for the PTUPT Grant No. 1335/PKS/ITS/2020 to support and funding of this research.

\section{REFERENCES}

[1] N. S. Octaviani, Semin, M. B. Zaman, "The implementation of CNG as an alternative fuel on marine diesel engine," International Journal of Mechanical Engineering and Technology., vol. 9 (13), pp. 24-33, 2018.

[2] L. Wei, "A Review on Natural Gas/Diesel Dual Fuel Combustion, Emissions and Performance," Fuel Processing., vol. 142, pp. 264278, 2016.

[3] N. S. Octaviani and Semin, "Study of Dual Fuel Engine as Environmentally Friendly Engine," International Journal of Mechanical and Mechatronics Engineering., vol. 13 (4), 2019.

[4] S. Imran, D. R. Emberson, B. Ihracska, D.S. Wen, R. J. Crookes, T. Korakianitis, "Effect of pilot fuel quantity and type on performance and emissions of natural gas and hydrogen-based combustion in compression ignition engine," International Journal of Hydrogen Energy., vol. 39(10), pp. 5163-5175, 2014.

[5] I. S. Seddiek, M. M. Elgohary, "Eco-friendly selection of ship emissions reduction strategies with emphasis on SOx and NOx emissions," International Journal of Naval Architecture and Ocean Engineering., vol. 6, pp 737-748, 2014.

[6] I. Taritas, M Sremec, D. Kozarac, M. Blazic, Z. Lulic, "The effect of operating parameters on dual fuel engine performance and emissions - An overview," Transactions of FAMENA, XLI-1, 2017.

[7] L. Jie, F. Yang, H. Wang, M. Ouyang, S. Hao, "Effect of pilot fuel quantity on the emission characteristics of a CNG diesel dual fuel engine with optimised pilot injection timing," Applied Energy., vol. 110, pp 201-206, Oct. 2013.

[8] B. B. Sahoo, N. Sahoo, U. K. Saha, "Effect of engine parameters and type of gaseous fuel on the performance of dual-fuel gas diesel engine - A critical review," Renewable and Sustainable Energy Reviews., vol. 13, pp 1151-1184, 2009.

[9] K. Murthy, N. Madhwesh, B. R. Shrinivasarao, "Influence of injection timing on the performance of dual fuel compression ignition engine with EGR," International Journal of Engineering Research and Development., vol. 1(11), pp 36-42, 2012.

[10] A. Zoltowski, "Investigation of combustion process in dual fuel diesel engine," Journal of KONES Powertrain and Transpor., vol. 21 (2), pp. 303-309, 2014.

[11] P. R. Jha, K. K. Srinivasan, S. R. Krishnan, "Influence of swirl ratio on diesel methane dual fuel combustion- A CFD investigation," Proceedings of ASME 2017 Internal Combustion Engine Fall Technical Conference., ICEF2017, 2017.

[12] H. Yerrennagoudaru, S. P. Desai, "Effect of inlet air swirl on four stroke single cylinder diesel engine performance," International 
Journal of Recent Development in Engineering and Technology., vol. 2(6), 2014.

[13] W. Chen, J. Pan, B. Fan, Y. Liu and O. Peter, "Effect of injection strategy on fuel air mixing and combustion on direct injection diesel rotary engine (DI-DRE)," Energy Conversion and Management., vol. 154, pp. 68-80, 2017.

[14] M. D. R. Kamal, S. Kaliappan, S. Socrates, G. J. Babu, "CFD Analysis of Single Cylinder IC Engine Inlet Swirl Valve, Department of Mechanical Engineering," Velammal Institute of Technology, Chennai, India, 2017.

[15] P. Olmeda, J. Martín, R. Novella, R.Carreño, "An adapted heat transfer model for engines with tumble motion," Universitat Politécnica de Valéncia, Camino de Vera, 2015.

[16] A. Clenci, A. Bîzîiac, P. Podevin, G. Descombes, M. Deligant and R. Niculescu, "Idle Operation with Low Intake Valve Lift in a Port Fuel Injected Engine", University of Pitesti, Romania, 2013.

[17] Semin. A. R. Ismail. and R.A. Bakar, "Investigation of GAS Engine Intake Port Gas Flow Temperature Based on Steady-State and Transient Simulation." European Journal of Scientific Research., vol. 22(3), 2008

[18] Semin. A.R. Ismail. R.A Bakar and I. Ali, "Heat Transfer Investigation of Intake Port Engine Based on Steady-state and Transient simulation," American Journal of Applied Sciences., vol. 5(11), 2008

[19] A. R. Ismail. R. A. Bakar, Semin. and I. Ali, "Computer Modelling for 4-Stroke Direct Injection Diesel Engine," Advanced Materials Research, vol. 33-37, 2008

[20] A.R. Ismail. R.A. Bakar and Semin, "An Investigation of Valve Lift Effect on Air Flow and CD of Four Stroke Engines Based on Experiment," American Journal of Applied Sciences., vol. 5(8), 2008.

[21] Semin, R.A. Bakar and A.R. Ismail, "Investigation of Diesel Engine Performance Based on Simulation," American Journal of Applied Sciences., vol. 5(6), 2008.

[22] Semin, R.A. Bakar and A.R. Ismail, "Computational Visualization and Simulation of Diesel Engines Valve Lift Performance Using CFD," American Journal of Applied Sciences., vol. 5(5), 2008.
[23] P. Prabhakaran, P. Ramesh, C. G. Saravana, M. Loganathan, E. J. Gunasekharan, "” Experimental and numerical investigation of swirl enhancing grooves on the flow and combustion characteristics of a DI diesel engine," energy., vol. 115, pp 1234-1245, 2016.

[24] R. Raj, K. Thundil, R. Manimaran, "Effect of swirl in a constan speed diesel engine using computational fluid dynamics," $C F D$ Letters., vol, 4(4), 2012.

[25] N. S. Octaviani and Semin, "Effect of Fin Addition on Inlet Valve on Air-Gas Intake Flow of Dual Fuel Engine Based on Computational Modelling," International Review of Mechanical Engineering., vol. 14 (1), pp. 18-24, 2020.

[26] Semin, M. B. Zaman, A. Santoso, "Effect of Compression Ratio Improvement on the Performance of Dual Fuel Engine," International Review of Mechanical Engineering., vol. 13(3), pp. 142-147, 2019.

[27] Semin, N. S. Octaviani., A. P. Gusti and M. B. Zaman, "Power Performance Characteristics Investigation of Gas Engine Using New Injector," International Journal of Applied Engineering Research, vol. 11(11), pp. 7462-7466, 2016.

[28] Semin, A. P. Gusti, N. S. Octaviani and M. B. Zaman, "Effect of New Injector on the Torque Performance Characteristics of Gas Engine," International Journal of Applied Engineering Research., vol. 11(11), pp. 7467-7471, 2016

[29] Semin, F. M. Felayati, B. Cahyono, M. B. Zaman, "Improvemen approaches for the combustion process of recent diesel natural gas dual fuel engines-A technical review," International Review of Mechanical Engineering., vol. 13(3), pp. 198-202, 2019.

[30] Semin, R. A. Bakar, "Simulation and experimental method for the investigation of compressed natural gas engine performance", International Review of Mechanical Engineering., vol. 7(7), 2013.

[31] Semin and R.A. Bakar, "Computational Modelling the Effect of New Injector Nozzle Multi Diameter Holes on Fuel-Air Mixing Homogeneous of CNG Engine", International Journal of Applied Engineering Research., vol. 9(21), 2014. 